Provided for non-commercial research and education use. Not for reproduction, distribution or commercial use.

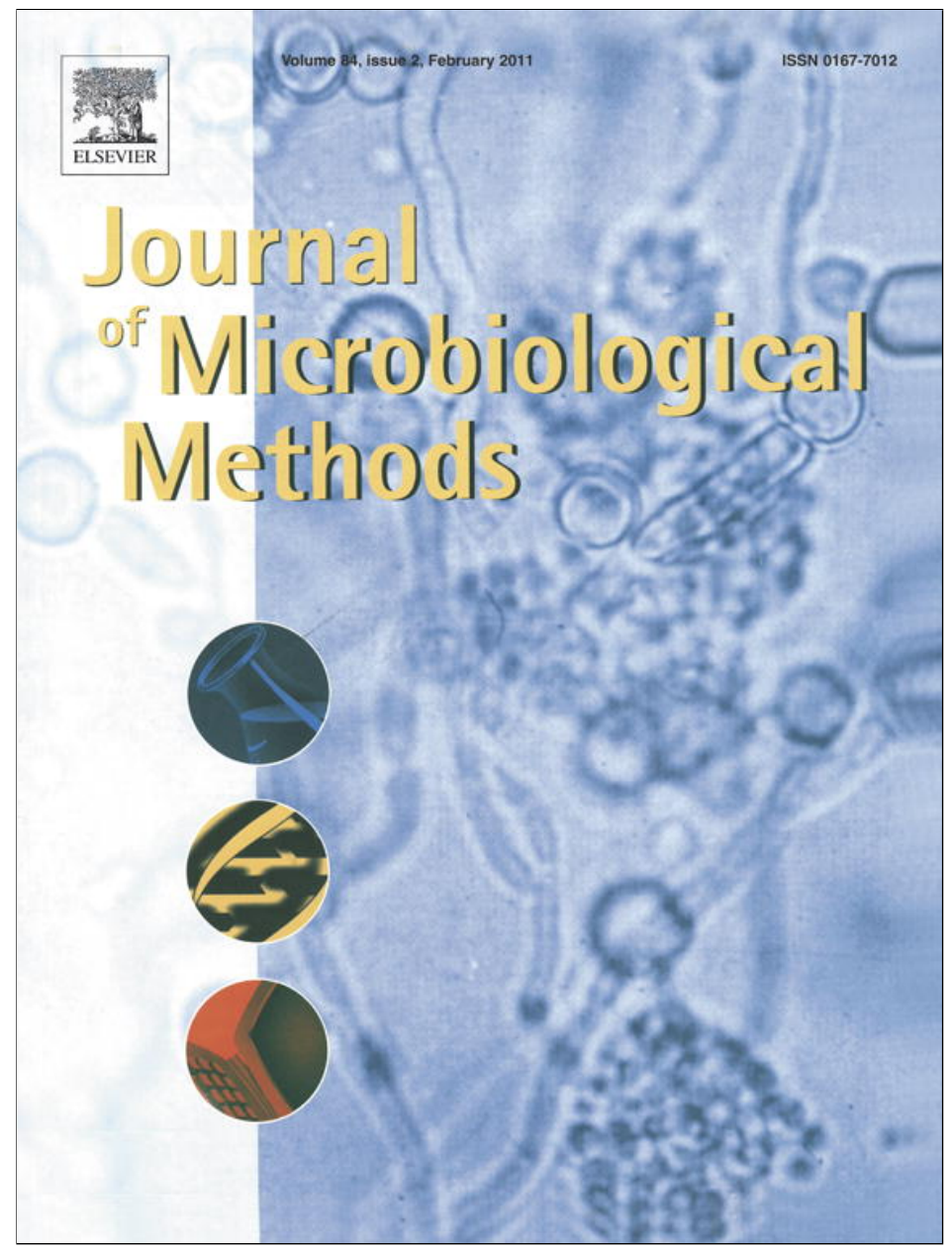

This article appeared in a journal published by Elsevier. The attached copy is furnished to the author for internal non-commercial research and education use, including for instruction at the authors institution and sharing with colleagues.

Other uses, including reproduction and distribution, or selling or licensing copies, or posting to personal, institutional or third party websites are prohibited.

In most cases authors are permitted to post their version of the article (e.g. in Word or Tex form) to their personal website or institutional repository. Authors requiring further information regarding Elsevier's archiving and manuscript policies are encouraged to visit:

http://www.elsevier.com/copyright 


\title{
Optimizing the growth of stressed Helicobacter pylori
}

\author{
Crystal L. Richards a, Brittany J. Buchholz ${ }^{\text {a }}$, Timothy E. Ford ${ }^{\mathrm{b}}$, Susan C. Broadaway ${ }^{\mathrm{a}}$, \\ Barry H. Pyle ${ }^{\mathrm{a}}$, Anne K. Camper ${ }^{\mathrm{a}, \mathrm{c}, *}$
}

a Department of Microbiology and Center for Biofilm Engineering, Montana State University, Bozeman, MT 59717, United States

${ }^{\mathrm{b}}$ Department of Research and Graduate Studies, University of New England, Biddeford, ME 04005, United States

c Department of Civil Engineering and Center for Biofilm Engineering, Montana State University, Bozeman, MT 59717, United States

\section{A R T I C L E I N F O}

\section{Article history:}

Received 1 October 2010

Received in revised form 15 November 2010

Accepted 15 November 2010

Available online 1 December 2010

\section{Keywords:}

H. pylori

Nonculturable

Resuscitation

Culturing

\begin{abstract}
A B S T R A C T
Helicobacter pylori is a Gram-negative bacterium that colonizes the human stomach and is responsible for causing gastric ulcers. H. pylori is known to become stressed and nonculturable after exposure to unfavorable conditions. In this study, we enhanced previously published resuscitation procedures, characterized conditions under which stressed $H$. pylori can be recovered, and formulated a selective and differential resuscitation medium. Results showed that a specialized broth supplemented with trace minerals and lysed human erythrocytes and serum is required for the recovery of nonculturable $H$. pylori. The type of stress was an important factor in the efficacy of resuscitation, with cells exposed to atmospheric oxygen more readily resuscitated than nutrient deprived cells. After resuscitation, culturable cells were recovered from previously nonculturable oxygen stressed cells ( 24 and $72 \mathrm{~h}$ of exposure) and nonculturable nutrient deprived cells ( $24 \mathrm{~h}$ of exposure). The length of time the cells were exposed to the stress was also an important factor in the recovery of stressed $H$. pylori. RNA levels were quantified and transcription of the cell division related gene, cdrA (HP0066), was assessed by qRT-PCR. The low levels of RNA detected in stressed cells, after resuscitation, support the idea that a small population of viable cells may be responsible for the colonies recovered on solid agar. The modification of the resuscitation broth into a selective and differential slant culture medium also allowed the recovery of stressed $H$. pylori. The methods presented here highlight the benefits and limitations of using human blood products for recovering nonculturable $H$. pylori.
\end{abstract}

(C) 2010 Elsevier B.V. All rights reserved.

\section{Introduction}

Helicobacter pylori is a Gram-negative, microaerophilic bacterium that colonizes the lining of the human stomach (Marshall, 1995; Veldhuyzen van Zanten and Sherman, 1994). This organism is responsible for causing gastric ulcers and increasing the risk of stomach cancer (Asaka et al., 2001; Moss and Malfertheiner, 2007). $H$. pylori is thought to infect approximately $50 \%$ of the human population worldwide and while the main route of transmission is likely fecal-oral (Kivi and Tindberg, 2006), it is possible that the organism may be contracted from the environment as well (Bellack et al., 2006; Sasaki et al., 1999).

Culture of $H$. pylori is the most accurate way of assessing viability (Saito et al., 2003), and isolation of the organism can allow testing for pathogenicity, antibiotic susceptibility, and for analyzing differences between strains. Culturing stressed $H$. pylori has long been problematic due to its oxygen sensitivity and ability to convert to a nonculturable form (Bode et al., 1993). Thus, culture of H. pylori recovered outside the

* Corresponding author. Center for Biofilm Engineering, Montana State University, EPS 366, Bozeman, MT 59717, United States. Tel.: + 1406994 4906; fax: + 14069946098. E-mail address: anne_c@biofilm.montana.edu (A.K. Camper). human host is a rare occurrence and research has depended primarily on molecular methods for identification from environmental samples (Bellack et al., 2006; Bunn et al., 2002; Janzon et al., 2009).

Cells in a nonculturable state will not grow on the traditional bacteriological media used for healthy cells (Oliver, 2000). They are thought to be dormant forms that may retain the potential to become metabolically active (Azevedo et al., 2007; Oliver, 2010). Nonculturable $H$. pylori have been characterized by many researchers (Adams et al., 2003; Bode et al., 1993; Byrd, 2000; Knight, 2000; Kusters et al., 1997), and are known to exhibit a characteristic transformation of cell shape from a rod to a coccoid form during the organism's life cycle and when exposed to stressful conditions (Bode et al., 1993). However, Adams and co-workers found that in a natural freshwater environment, cell morphology was not associated with culturability (Adams et al., 2003).

Resuscitation of $H$. pylori requires the restoration of culturability on routine bacteriological media (Oliver, 2000). Reports of resuscitation or regrowth of nonculturable $H$. pylori have shown variable results with limited testing conditions (Andersen et al., 1997; Cellini et al., 1998; Kurokawa et al., 1999). Andersen and co-workers reported visual confirmation of the transformation from nonculturable coccoid to spiral morphology along with full recovery of urease activity when erythrocyte lysate was added to the culture medium 
(Andersen, et al., 1997). This report was followed by Kurokawa et al. (1999) who found that the recovery of culturable cells on solid agar depended on using human blood serum and lysate.

Membrane integrity, ATP production and mRNA transcription have all been used as indicators of viability (Adams et al., 2003; Conway and Schoolnik, 2003; Gribbon and Barer, 1995; Nilsson et al., 2002; Sheridan et al., 1998). Nonculturable H. pylori cells can maintain their cell membrane integrity, and produce ATP and mRNA long after losing the ability to grow on a solid agar (Adams et al., 2003; Enroth et al., 1999; Gribbon and Barer, 1995; Nilsson et al. 2002). However, it is unknown if the nonculturable forms of $H$. pylori contribute to an overall low RNA and ATP yield or if a few viable cells retain full energy supplies because measurements are typically averaged across batch cultures or rely on qualitative measurements (Enroth et al., 1999; Narikawa et al., 1997; Nilsson et al., 2002). It is well known that gene transcription levels are greatly affected by environmental stimuli, mRNA molecules generally have a fast turnover (from seconds to $20 \mathrm{~min}$ ), and that mRNA disappears after cells are killed (Conway and Schoolnik, 2003; Sheridan et al., 1998), which makes mRNA molecules useful indicators of viability in batch cultures.

The aim of this study was to evaluate the potential for recovery of nonculturable $H$. pylori and characterize the conditions under which that recovery may occur. Because the recovery of stressed $H$. pylori has been attempted by several groups with mixed results, it was important to carefully characterize the efficacy of current resuscitation techniques. As a second measure of viability, we compared concentrations of total RNA and transcription of the cell division related gene $\mathrm{A}, c d r A$, before and after treatment with the resuscitation technique. The cell division related gene $(c d r A)$ has been shown to play a role in cell morphology and culturability under high salt conditions (Takeuchi et al., 1998). This study also describes the preparation of a potentially selective and differential regrowth medium.

\section{Materials and methods}

\subsection{Routine culturing}

H. pylori 26695 was obtained from the American Type Culture Collection (ATCC 700392) and was routinely grown from frozen stocks on tryptic soy agar (TSA) (Difco, Milwaukee, WI) with $5 \%$ sheep blood (Quad V, Montana) and the antibiotics vancomycin (Sigma, St. Louis, MO) $10 \mu \mathrm{g} / \mathrm{ml}$, trimethoprim (MP Biomedical, Solon, $\mathrm{OH}$ ) $0.5 \mu \mathrm{g} / \mathrm{ml}$, cefsulodin (Sigma) $0.5 \mu \mathrm{g} / \mathrm{ml}$, polymixin B (Sigma) $3.5 \mathrm{U} / \mathrm{ml}$ and amphotericin B (Sigma) $7.5 \mu \mathrm{g} / \mathrm{ml}$. This combination of antibiotics has been shown to have few deleterious effects on $H$. pylori growth (Degnan et al., 2003; Stevenson et al., 2000) and initial cultivation on antibiotics helped inhibit contamination of cultures after subculturing onto media without antibiotics. The plates were incubated in a microaerophilic atmosphere using GasPak ${ }^{\mathrm{TM}}$ EZ Campy sachets (Becton Dickinson and Co., Franklin Lakes, NJ) in a BBL anaerobe jar for $48 \mathrm{~h}$ at $37^{\circ} \mathrm{C}$. Cells were gently removed from agar using sterile swabs and were inoculated into tryptic soy broth (TSB) (Difco) with $5 \%$ bovine calf serum (Thermo Scientific Hyclone, Logan UT) followed by inoculation into biphasic slants.

\subsection{Preliminary testing}

The growth media published by Kurokawa et al. (1999) was used initially to confirm the resuscitation of stressed $H$. pylori. Briefly, H. pylori was grown confluently (ca. $1 \times 10^{7} \mathrm{CFU} / \mathrm{ml}$ ) on TSA with $5 \%$ sheep blood at $37{ }^{\circ} \mathrm{C}$ in a microaerophilic atmosphere and subsequently subjected to either oxygen stress or nutrient deprivation. $\mathrm{H}$. pylori grown confluently on TSA with sheep blood for $48 \mathrm{~h}$ were used as a positive control. Oxygen stress consisted of removing healthy $48 \mathrm{~h} \mathrm{H}$. pylori cultures from the microaerophilic incubation chambers and placing them in a $37{ }^{\circ} \mathrm{C}$ incubator in the presence of atmospheric levels of oxygen. The nutrient deprivation treatment consisted of removing $48 \mathrm{~h} \mathrm{H}$. pylori cultures from the microaerophilic incubation chambers and gently removing the cells with a sterile inoculation loop into sterile ultrapure water. The cells were rinsed by centrifugation at $13,000 \times g$ for 3 min twice, resuspended in sterile ultrapure water, and incubated at $37{ }^{\circ} \mathrm{C}$ under atmospheric conditions. The oxygen and nutrient stressed $(24,72$, and $168 \mathrm{~h}$ of exposure) $H$. pylori were then subjected to resuscitation as previously described (Kurokawa et al., 1999).

\subsection{Biphasic slant culture and stress treatments}

Initially, routine cultivation of $H$. pylori showed that growth in different broth media (tryptic soy broth, brain heart infusion broth, Brucella broth, and Ham's F-12, all supplemented with $5 \%$ fetal calf serum) was variable and irreproducible. This observation and the desire to grow large quantities of cells in a liquid medium led to the investigation of different methods of cultivation for $\mathrm{H}$. pylori. The blood agar biphasic slant growth system described by ATCC (Anonymous, 2005) was found to allow growth of large numbers of cells in a highly reproducible fashion. Slants were made in $50 \mathrm{ml}$ culture tubes (Fisher Scientific) each containing $25 \mathrm{ml} \mathrm{TSA}$ and 5\% sheep blood with no antibiotics, solidified at an angle with a pool of $5-10 \mathrm{ml}$ of TSB placed at the bottom of the slant. H. pylori cells were grown as described in Section 2.1, removed from the TSA with sheep blood and suspended in TSB (with 5\% calf serum). The suspended cells were then added to a TSA slant at ca. $1 \times 10^{7} \mathrm{CFU} / \mathrm{ml}$ and incubated for $24 \mathrm{~h}$ in a microaerophilic atmosphere at $37^{\circ} \mathrm{C}$. After incubation, cells from the slants were either used directly (healthy cells for positive control) or were subjected to oxygen or nutrient deprivation.

To induce oxygen stress, inoculated slants were removed from the microaerophilic atmosphere and placed in a $37^{\circ} \mathrm{C}$ incubator with atmospheric oxygen levels. $H$. pylori cells subjected to nutrient deprivation were decanted from the biphasic slant and centrifuged at $13,000 \times g$ for $3 \mathrm{~min}$. The cells were washed twice with sterile ultrapure water, resuspended in sterile ultrapure water, and incubated in a $37^{\circ} \mathrm{C}$ incubator with atmospheric oxygen. Aliquots of stressed cells were plated onto TSA agar with $5 \%$ sheep blood at $24 \mathrm{~h}$ intervals to assess culturability. Both stress treatments were sufficient to inhibit the formation of colonies on TSA + sheep blood after $24 \mathrm{~h}$.

\subsection{Optimized regrowth medium ( $R$ broth)}

The optimized regrowth media ( $\mathrm{R}$ broth) developed in this study consisted of Brucella broth (Difco) with $10 \mathrm{mM}$ Hepes (Sigma), at a $\mathrm{pH}$ of 7.8, $0.2 \mu \mathrm{M} \mathrm{CuSO}_{4}$ (Sigma), $0.2 \mu \mathrm{M} \mathrm{MnSO}_{4}$ (Sigma), $3 \mu \mathrm{M} \mathrm{ZnSO}{ }_{4}$ (Sigma), with $50 \mu \mathrm{M} \mathrm{FeSO}_{4}$ (Sigma), $250 \mu \mathrm{M} \mathrm{MgCl} 2$ (Fisher scientific, Fair Lawn NJ), $250 \mathrm{mg} / \mathrm{l}$ sodium pyruvate (Fisher Scientific), $2 \%$ human blood serum, and $2 \%$ human blood lysate added after autoclaving. The broth was based on studies performed by Andersen et al. (1997); Kurokawa et al. (1999); and Testerman et al. (2001, 2006). Differing concentrations of $\mathrm{MgCl}_{2}, \mathrm{FeSO}_{4}, \mathrm{ZnSO}_{4}$ and sodium pyruvate were added to the base medium and evaluated to optimize the growth of healthy and stressed H. pylori. Qualitative assessments of the growth of the cells after varying the compounds were performed to check for inhibition and/or promotion of growth. Assessments were performed by spread plating aliquots of inoculated broth formulations onto TSA with sheep blood and incubating the plates microaerophilically for up to 7 days while monitoring every $48 \mathrm{~h}$ for growth. Human blood serum was produced by centrifugation of citrated whole blood (Innovative Research, Novi, MI) at $15,000 \times \mathrm{g}$ for $10 \mathrm{~min}$, the supernatant was removed and added directly to $\mathrm{R}$ broth. Human blood lysate was produced by three freeze/thaw/sonicate cycles; blood cells were sonicated for $1 \mathrm{~min}$, frozen at $-80^{\circ} \mathrm{C}$ for $15 \mathrm{~min}$, and 
thawed at room temperature. Blood samples were examined microscopically to confirm lysis.

The $H$. pylori cells grown in biphasic slants and given the oxygen and nutrient deprivation stress treatments were used with the $\mathrm{R}$ broth optimization for the final experiments. Five milliliters of cells from each stress treatment were centrifuged at $13,000 \times \mathrm{g}$ for $3 \mathrm{~min}$, washed twice in phosphate buffered saline (PBS) with $10 \mathrm{mM}$ ammonium sulfate (Sigma) and resuspended into $500 \mu$ l working stock PBS with $10 \mathrm{mM}$ ammonium sulfate. Phosphate buffered saline was composed of $12 \mathrm{~g} / \mathrm{l}$ sodium phosphate monobasic (Fisher Scientific), $2.2 \mathrm{~g} / \mathrm{l}$ sodium phosphate dibasic (J. T. Baker Chemical Co., Phillipsburg, NJ), and $85 \mathrm{~g} / \mathrm{l}$ sodium chloride (Fisher Scientific) and diluted $1: 10$ to obtain a working stock solution. Because it has been shown to enhance resuscitation in both $H$. pylori and Vibrio cholerae, stressed H. pylori cells were heat shocked $\left(37^{\circ} \mathrm{C}\right.$ for $10 \mathrm{~min}, 45^{\circ} \mathrm{C}$ for $30 \mathrm{~s}$. and cooled to $4{ }^{\circ} \mathrm{C}$ ) (Kurokawa et al., 1999; Wai et al., 1996). Heat shocked cells were added to $\mathrm{R}$ broth and incubated in a microaerophilic atmosphere for up to 7 days and monitored every $48 \mathrm{~h}$ at $37^{\circ} \mathrm{C}$. All treatments were repeated in triplicate.

\subsection{Selective and differential growth medium}

To assess if a resuscitation method based on the $\mathrm{R}$ broth could be modified to accommodate environmental samples, we created a selective and differential biphasic growth medium that allows selection using antibiotics and presumptive identification using phenol red. Seven grams of Bacto ${ }^{\mathrm{TM}}$ agar (Becton Dickinson and Co.) and $50 \mathrm{mg}$ of phenol red (Difco) were added to Brucella broth with $10 \mathrm{mM}$ hepes pH7.8, $0.2 \mu \mathrm{M} \mathrm{CuSO}_{4}$ (Sigma), $0.2 \mu \mathrm{M} \mathrm{MnSO}_{4}$ (Sigma), and $3 \mu \mathrm{M}$ $\mathrm{ZnSO}_{4}$ (Sigma), prior to autoclaving. After autoclaving, $50 \mu \mathrm{M} \mathrm{FeSO}$ (Sigma), $250 \mu \mathrm{M} \mathrm{MgCl}_{2}$ (Fisher scientific), $250 \mathrm{mg} / \mathrm{l}$ sodium pyruvate (Fisher Scientific), $0.6 \mathrm{~g} / \mathrm{l}$ urea (Sigma), $10 \mu \mathrm{g} / \mathrm{ml}$ vancomycin, $0.5 \mu \mathrm{g} /$ $\mathrm{ml}$ trimethoprim, $0.5 \mu \mathrm{g} / \mathrm{ml}$ cefsulodin, $3.5 \mathrm{U} / \mathrm{ml}$ polymyxin $\mathrm{B}$ and $7.5 \mu \mathrm{g} / \mathrm{ml}$ amphotericin B were added to the cooled liquid and the final $\mathrm{pH}$ adjusted to 5.7. Urea was added as a substrate for the urease enzyme which converts urea to ammonia and bicarbonate. The activity of the urease enzyme and subsequent increase in $\mathrm{pH}$ associated with the production of ammonia and bicarbonate causes the phenol red indicator to change from a yellow-orange color to a bright red color. Twenty-five milliters of the agar was added to a $50 \mathrm{ml}$ culture tube and solidified at an angle and $5 \mathrm{ml}$ of $\mathrm{R}$ broth (as previously described) was added to each slant. Five milliliters of cells from each stress treatment ( 24 and $72 \mathrm{~h}$ time points were used) was centrifuged at $13,000 \times \mathrm{g}$ for $3 \mathrm{~min}$, followed by washing twice in PBS with $10 \mathrm{mM}$ ammonium sulfate and resuspension into $500 \mu \mathrm{l}$ PBS with $10 \mathrm{mM}$ ammonium sulfate. Stressed $\mathrm{H}$. pylori cells were heat shocked $\left(37^{\circ} \mathrm{C}\right.$ for $10 \mathrm{~min}, 45^{\circ} \mathrm{C}$ for $30 \mathrm{~s}$. and cooled to $4{ }^{\circ} \mathrm{C}$ ). Heat shocked cells were added to $\mathrm{R}$ slant, incubated in a microaerophilic atmosphere for $48 \mathrm{~h}$ at $37^{\circ} \mathrm{C}$, and monitored for color change and growth on the slant surface. Aliquots of the R slant broth pool were plated on TSA with sheep blood to check for consistency with results seen in $\mathrm{R}$ broth experiments.

\subsection{Total and culturable cell counts}

For comparison and as enumeration controls, total and culturable cell counts were performed on oxygen and nutrient deprived $H$. pylori cells before and after resuscitation. To enumerate the total number of cells per sample, aliquots of $H$. pylori cells at each time interval and treatment were fixed in $4 \%$ formaldehyde and incubated with 100x SYBR Green (Invitrogen, Carlsbad, CA) stain at room temperature for up to an hour. SYBR Green was obtained from Invitrogen at a concentration of $10,000 \times$ and diluted $1: 100$ to obtain a $100 \times$ working stock solution. Cells were diluted if appropriate, filtered by a vacuum pump onto a 0.22 polycarbonate $\mu \mathrm{m}$ filter (Whatman, Maidstone, England), and visualized on a Zeiss Axioskop epifluorescence micro- scope (Carl Zeiss, Inc., Maple Grove, MN) for enumeration of total cells. The microscope utilized the Chroma set \#41001 filter with excitation at $480 / 40$ and emission at 535/50. A total of 20 fields or 400 cells were counted per filter and duplicate filters were counted for each biological replicate. Because the gold standard for in vitro culturability is growth on solid agar, each resuscitation treatment was subcultured onto a widely accepted growth medium for H. pylori, TSA with sheep blood (prepared as described by ATCC) (Anonymous, 2005 ) after the $48 \mathrm{~h}$ incubation period. Culturable cells were enumerated by diluting, if appropriate, and plating on TSA with sheep blood with and without antibiotics to check for contamination. Duplicate plates were counted for each biological replicate.

\subsection{RNA extraction, purification and quantitative reverse transcriptase $P C R$}

RNA was extracted from healthy cells at time zero of stress treatment and from stressed cells at 24,72, and $168 \mathrm{~h}$ before and after the resuscitation treatment. The cells were pelleted at $4{ }^{\circ} \mathrm{C}$ for $5 \mathrm{~min}$ at $13,000 \times g$ and the supernatant was removed. Hot Trizol ${ }^{\circledR}$ (Invitrogen, Carlsbad, CA) $\left(65^{\circ} \mathrm{C}\right)$ was added followed by brisk pipetting of the cells to remove all clumps. This step was crucial to lysis of cells and release of RNA. Trizol ${ }^{\circledR}$ was incubated at $65{ }^{\circ} \mathrm{C}$ for 5 min with vortexing on maximum every minute for $10 \mathrm{~s}$ and subsequently incubated at room temperature for $5 \mathrm{~min}$. One hundred microliters of ice-cold chloroform was added to the Trizol ${ }^{\circledR}$ and the tubes were shaken for $15 \mathrm{~s}$ followed by incubation at room temperature for 2-3 min. The top aqueous layer was added to $250 \mu \mathrm{l} 100 \%$ ethanol and then applied directly to an RNeasy column (Qiagen, Valencia, CA) and treated according to the manufacturer's instructions. RNA samples were subsequently treated to remove DNA contamination using the commercially available TURBO DNase treatment (Ambion, Austin, TX) according to the manufacturer's instructions with the following modification. The rigorous treatment was used with an extra round of incubation with DNase (total of $3 \mu$ added). RNA samples were subsequently stored at $-20^{\circ} \mathrm{C}$.

RT-PCR was used for this experiment using a one step QuantiTect SYBR Green kit (Qiagen) in a $25 \mu$ total volume. The mixture contained $1.25 \mu \mathrm{l}(0.5 \mathrm{mmol})$ forward and reverse primers, $12.5 \mu \mathrm{l}$ master mix, $0.25 \mu \mathrm{l}$ RT mix, $10 \mathrm{ng}$ RNA, and $4.75 \mu \mathrm{l}$ water. The assay was carried out at $50{ }^{\circ} \mathrm{C}$ for $30 \mathrm{~min}$ and denaturation at $95^{\circ} \mathrm{C}$ for $15 \mathrm{~min}$. Thirty cycles were run at $94^{\circ} \mathrm{C}$ for $15 \mathrm{~s}, 60^{\circ} \mathrm{C}$ for $30 \mathrm{~s}$ followed by a 30 min extension step at $72{ }^{\circ} \mathrm{C}$. The primers were designed using Primer 3 and the NCBI database containing the full genome sequence of $H$. pylori 26695. Primers were based on the $c d r A$ gene, HP0066, and are as follows: cdrA-R, 5' GCC ACA GAC AAC GAG CAG TA, cdrA-L 5'AGC GCT CAA GTT CTC ACC AT. Standard curves were prepared using serially diluted gene specific PCR products generated from randomly primed reference cDNA (Invitrogen, Valencia CA). Two technical replicates were performed on each biological replicate to control for variation in the assay. A negative control without reverse transcriptase was included for every RNA sample to detect contamination by DNA and RNA-free controls were routinely run with reagents and each primer set to detect RNA contamination.

\subsection{Statistical analysis}

All data were compiled and for all instances where plate count values had a value of zero indicating none detected, a substitution rule was used (USEPA, 1998). The detection limit of the plate culture technique used in this study was $10 \mathrm{CFU} / \mathrm{ml}$ and was chosen to replace all zero plate counts so that log transformations could be performed. Accordingly, a log value of 1 was used for statistical analysis on all samples that had CFU recovery below the detection limit. To assess differences in mean total and viable cell counts before and after treatment with $\mathrm{R}$ broth, paired t-tests were applied in Minitab ${ }^{\circledR}$. 
Welch's two-sample t-test was performed to assess significant differences in mean total and culturable cell counts between the stress groups, oxygen stress and nutrient deprivation (Kutner et al., 2004). Welch's two-sample $t$-test (Kutner et al., 2004) was performed to assess significant differences in mean $c d r A$ expression in healthy and stressed cells, before and after resuscitation. A confidence level of 0.05 was used to determine statistical significance.

\section{Results}

\subsection{Preliminary results}

This report defines culturable as the ability of a cell to grow on a solid agar medium, forming a visible colony in vitro and is indicated by colony forming units (CFU). Initial experiments used $H$. pylori confluently grown on TSA with sheep blood and subjected to oxygen and nutrient deprivation stresses. The resuscitation broth tested initially was described by Kurokawa et al. (1999), and is a mixture of Brucella broth, Hepes, trace minerals, sodium pyruvate, human blood serum and lysed erythrocytes. To assess the usefulness of the resuscitation broth, a series of 10 biological replicates of each stress condition was performed over a period of three months. Stressed cells were incubated in the resuscitation medium for $48 \mathrm{~h}$ and subcultured onto TSA with sheep blood. Overall, 6 of 10 air stressed and 5 of 10 nutrient deprived $H$. pylori replicates showed regrowth after incubation in the resuscitation broth and subsequent subculture. Of note is that after approximately 45 days of storage, the human blood products (lysed erythrocytes and serum, stored at $-20^{\circ} \mathrm{C}$ ) could no longer support growth of the organism. When fresh blood products were obtained, the assay again allowed regrowth of stressed $H$. pylori on solid agar.

H. pylori is known to have specific nutritional requirements for in vitro growth and varying these compounds can affect growth (Testerman et al., 2001, 2006). To optimize regrowth, the concentrations of ferrous sulfate, magnesium chloride, and zinc sulfate were varied from starting concentrations of $2.5 \mu \mathrm{M}, 200 \mu \mathrm{M}$, and $0.2 \mu \mathrm{M}$, respectively to final concentrations of $50 \mu \mathrm{M}, 250 \mu \mathrm{M}$ and $3 \mu \mathrm{M}$ respectively. Aliquots of cells from each broth formulation were plated onto TSA with sheep blood and observations assessing results were qualitative, ranging from no growth, light, medium, and heavy growth. While the initial concentrations of trace minerals supported heavy growth of healthy cells and light growth of stressed H. pylori, increasing iron, magnesium, and zinc allowed heavier growth of stressed H. pylori. When any of the three metals were omitted from the broth, no growth was observed. The addition of trace minerals to culture media has been previously investigated by Testerman et al. (2006) and shown to greatly affect in vitro culture of $H$. pylori. Additionally, varying concentrations of sodium pyruvate were evaluated (50 mg/l, $110 \mathrm{mg} / \mathrm{l}$, and $250 \mathrm{mg} / \mathrm{l}$ ) with all concentrations supporting growth of healthy and stressed cells while growth was inhibited when it was omitted. A summary of the components contained in $\mathrm{R}$ broth is listed in Table 2 .

\subsection{Culture of stressed H. pylori}

H. pylori cells were grown in TSA blood agar biphasic slants due to the highly reproducible and robust growth observed with this culture method. Cells were grown as described in Section 2.1 for $24 \mathrm{~h}$ followed by either oxygen stress or nutrient deprivation by incubation in water, both at $37^{\circ} \mathrm{C}$. Positive controls (healthy cells, presumed to be in early log phase) were grown for $24 \mathrm{~h}$ on the bisphasic slants. The addition of healthy $H$. pylori cells to the optimized $\mathrm{R}$ broth medium did not significantly increase the total cell numbers $(3.92 \times$ $10^{7}$ cells/ml before resuscitation to $3.96 \times 10^{7}$ after resuscitation $(P=0.935))$ (Time Zero, Fig. 1$)$. However, there was a statistically significant increase in culturable cells (CFU) after resuscitation of healthy cells from approximately $1.98 \times 10^{6} \mathrm{CFU} / \mathrm{ml}$ before resuscitation to $2.70 \times 10^{7} \mathrm{CFU} / \mathrm{ml}$ after resuscitation $(P=0.036)$.

H. pylori cells grown in biphasic culture were subjected to oxygen stress for up to $168 \mathrm{~h}$ ( 7 days) and were nonculturable when subcultured on TSA with sheep blood within $24 \mathrm{~h}$ of exposure to stress treatment. Oxygen stress caused a switch in cell morphology from the typical spiral shape to a coccoid, with the cells nearing $100 \%$ coccoid after two weeks (data not shown). After resuscitation, there were statistically significant increases in both total (cells/ml) and culturable $(\mathrm{CFU} / \mathrm{ml}$ ) counts in samples that had been subjected to oxygen stress for 24 and $72 \mathrm{~h}$ (Fig. $1 \mathrm{~A}$ and B). After $24 \mathrm{~h}$ of exposure to atmospheric conditions and subsequent resuscitation treatment, the mean total number of cells increased from $4.6 \times 10^{6}$ to $7.2 \times 10^{7}$ cells/ $\mathrm{ml}(P=0.027)$ and the mean culturable colony counts increased from none detected to $1.1 \times 10^{4} \mathrm{CFU} / \mathrm{ml}(P=0.001)$. After $72 \mathrm{~h}$ of oxygen stress and subsequent resuscitation treatment, the mean total number of cells increased from $2.4 \times 10^{6}$ to $1.4 \times 10^{7}$ cells $/ \mathrm{ml}(P=0.040)$ and the mean culturable colony counts increased from none detected to $1.3 \times 10^{4} \mathrm{CFU} / \mathrm{ml}(P=0.000)$. After resuscitation, there was no recovery of culturable cells that had been exposed to atmospheric oxygen for $168 \mathrm{~h}$ (Fig. 1A).

H. pylori cells grown in biphasic culture were treated with nutrient deprivation for up to $168 \mathrm{~h}$ and became nonculturable when subcultured on TSA with sheep blood within $24 \mathrm{~h}$ of stress treatment. Nutrient deprived cells showed a much slower conversion of the cells to the coccoid morphology with approximately $45 \%$ of the cells coccoid after two weeks (data not shown). After $24 \mathrm{~h}$ of nutrient deprivation, the mean total cell counts did not significantly change $\left(2.8 \times 10^{7}\right.$ cells $/ \mathrm{ml}$ before resuscitation to $3.1 \times 10^{7}$ cells $/ \mathrm{ml}$ after resuscitation $(P=0.965)$ ) however, there was an increase in culturable cell counts from none detected before treatment to ca. $1 \times 10^{3} \mathrm{CFU} / \mathrm{ml}$ after treatment $(P=0.062)$ (Fig. 1D). $H$. pylori that were nutrient deprived for $72 \mathrm{~h}$ or $168 \mathrm{~h}$ showed no significant change in total cell counts or culturable cells (CFU) after the resuscitation treatment and subsequent subculture on TSA with sheep blood.

The total number of cells did not differ between the two types of stress treatments (Table 1) which indicates that neither stress condition caused lysis of the organisms over time. However, the cells responded differently to the two stresses. H. pylori exposed to oxygen stress for $24 \mathrm{~h}$ recovered more colony forming units on TSA with sheep blood than nutrient deprived $H$. pylori at $24 \mathrm{~h}$, but both stress treatments had culturable cells (CFUs) after resuscitation. After $72 \mathrm{~h}$, only the oxygen stress treatment had culturable cells when subcultured after resuscitation. After $168 \mathrm{~h}$, neither stress treatment yielded culturable cells after incubation in $\mathrm{R}$ broth and subsequent subculture on TSA with sheep blood. Both treatments showed that length of stress was a factor in the ability to be resuscitated, and suggests that optimization of recovery media should include investigations with a variety of stress conditions.

RNA yields of $H$. pylori, after RNeasy purification and DNase treatment, varied significantly depending on the stress treatment. RNA extracted from $H$. pylori grown to early log phase, $24 \mathrm{~h}$, yielded the largest amounts of total RNA with a mean and standard deviation of $35.3 \pm 5.7 \mu \mathrm{g}$ total RNA. RNA extracted from oxygen stressed cells decreased substantially over time to $6.1 \pm 1.1 \mu \mathrm{g}$ total RNA at $24 \mathrm{~h}, 2.7 \pm 0.9 \mu \mathrm{g}$ total RNA at $72 \mathrm{~h}$, and $1.4 \pm 0.5 \mu \mathrm{g}$ total RNA at $168 \mathrm{~h}$. H. pylori cells that had been exposed to oxygen stress for 24,72 , and $168 \mathrm{~h}$ and then given the resuscitation treatment had $4.8 \pm 2.2 \mu \mathrm{g}, 8.6 \pm 2.9 \mu \mathrm{g}$, and $1.5 \pm 0.4 \mu \mathrm{g}$ of total RNA, respectively. RNA extracted from nutrient deprived cells decreased more gradually; $7.7 \pm 1.2 \mu \mathrm{g}$ total RNA at $24 \mathrm{~h}, 9.7 \pm 2.2 \mu \mathrm{g}$ total RNA at $72 \mathrm{~h}$, and $3.3 \pm 1.8 \mu \mathrm{g}$ total RNA at $168 \mathrm{~h}$. The nutrient deprived cells showed a rapid decrease in RNA levels after treatment with R broth, with total RNA of $1.6 \pm 1.0 \mu \mathrm{g}$ at $24 \mathrm{~h}, 4.5 \pm$ $3.2 \mu \mathrm{g}$ at $72 \mathrm{~h}$, and $2.3 \pm 1.3 \mu \mathrm{g}$ at $168 \mathrm{~h}$ of exposure to stress and subsequent treatment. 

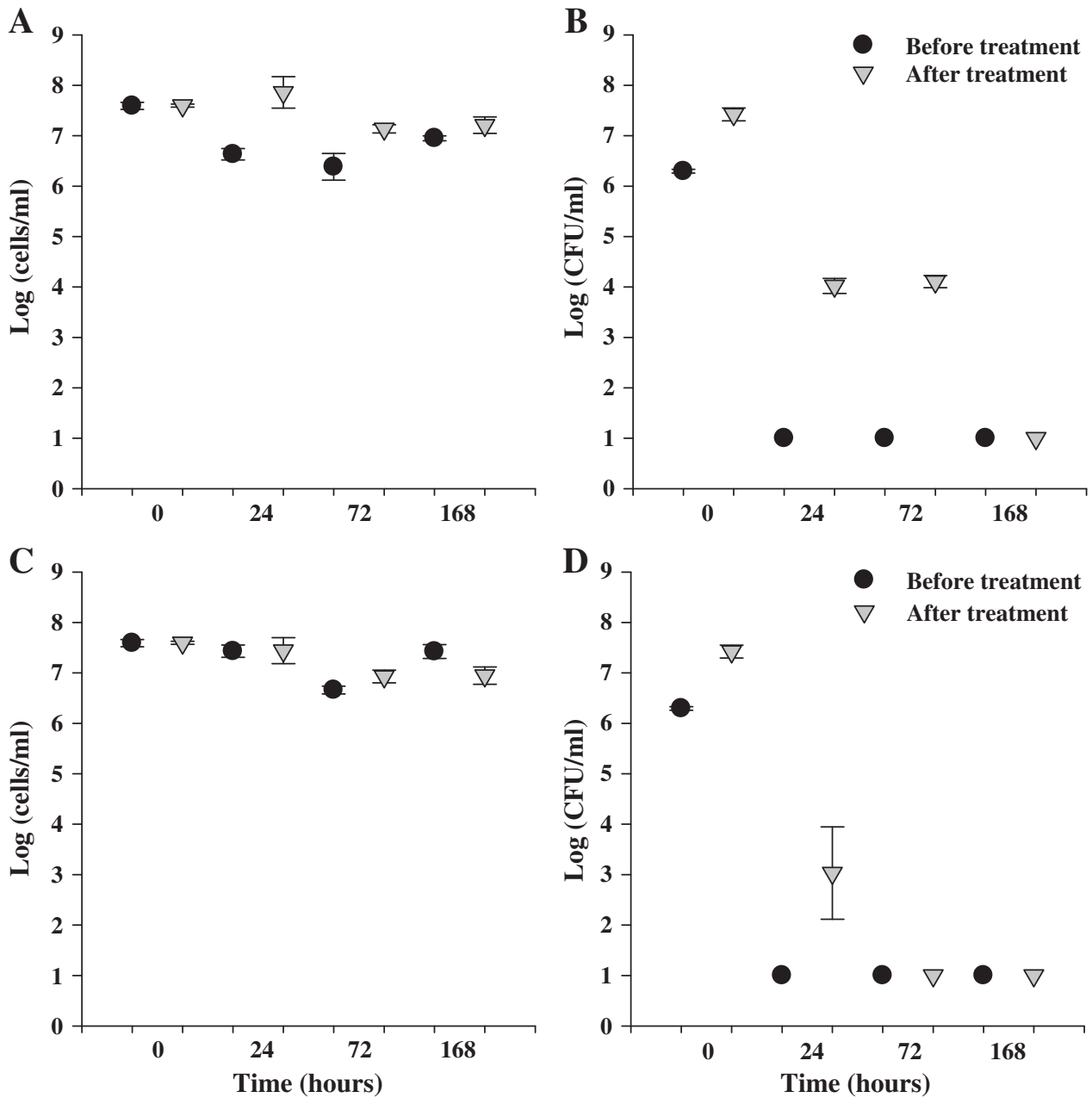

Fig. 1. Depicts the total cell and culturable colony counts from $H$. pylori before and after resuscitation. Symbols indicate mean counts of three independent biological replicates (cells/ $\mathrm{ml}$ or $\mathrm{CFU} / \mathrm{ml}$ ), error bars indicate 1 standard deviation. For comparison, time zero in all graphs is positive control healthy cells grown in biphasic slant before and after resuscitation A) Oxygen stressed total cell counts sampled at 24, 72 and $168 \mathrm{~h}$ before and after resuscitation. B) Oxygen stressed colony counts sampled at 24,72 , and $168 \mathrm{~h}$ before and after resuscitation. C) Nutrient deprived total cell counts sampled at 24, 72 and $168 \mathrm{~h}$ before and after resuscitation. D) Nutrient deprived colony counts sampled at 24,72 and $168 \mathrm{~h}$ before and after resuscitation. One log (CFU/ml) was the detection limit for culturable cells.

Due to its putative role in repression of cell division, the transcription of $c d r A$ was chosen for study as a potential candidate for regulating the loss in culturability seen in H. pylori during stress. A qRT-PCR assay was performed to assess the levels of $c d r A$, on positive

Table 1

Comparison of the differences in mean total cell (cells/ml) and mean culturable cell $(\mathrm{CFU} / \mathrm{ml})$ counts between the oxygen stress and nutrient deprivation treatments before and after resuscitation.

\begin{tabular}{|c|c|c|c|c|c|c|}
\hline $\begin{array}{l}\text { Time } \\
\text { (h) }\end{array}$ & $\begin{array}{l}\text { Oxygen before } \\
\text { R broth }\end{array}$ & $\begin{array}{l}\text { Nutrient before } \\
\mathrm{R} \text { broth }\end{array}$ & $P$ value & $\begin{array}{l}\text { Oxygen after } \\
\mathrm{R} \text { broth }\end{array}$ & $\begin{array}{l}\text { Nutrient after } \\
\mathrm{R} \text { broth }\end{array}$ & $P$ value \\
\hline \multicolumn{7}{|c|}{ Total cells (cells/ml) } \\
\hline 24 & $4.38 \times 10^{6}$ & $8.43 \times 10^{7}$ & 0.004 & $2.77 \times 10^{7}$ & $3.06 \times 10^{7}$ & 0.173 \\
\hline 72 & $2.69 \times 10^{6}$ & $1.38 \times 10^{7}$ & 0.221 & $4.63 \times 10^{6}$ & $8.72 \times 10^{6}$ & 0.097 \\
\hline 168 & $8.91 \times 10^{6}$ & $1.69 \times 10^{7}$ & 0.030 & $2.74 \times 10^{7}$ & $9.32 \times 10^{6}$ & 0.151 \\
\hline \multicolumn{7}{|c|}{ Viable cells (CFU/ml) } \\
\hline 24 & nd & $\mathrm{Nd}$ & $*$ & $1.09 \times 10^{4}$ & $2.63 \times 10^{3}$ & 0.205 \\
\hline 72 & nd & $\mathrm{Nd}$ & * & $1.31 \times 10^{4}$ & nd & 0.000 \\
\hline 168 & nd & $\mathrm{Nd}$ & * & nd & nd & \\
\hline
\end{tabular}

(nd) not detected.

* No difference between oxygen stress and nutrient deprivation treatments. control H. pylori (early log phase) and both oxygen and nutrient stress treatments (all 3 time points for both treatments) before and after transfer to $\mathrm{R}$ broth. All reactions were negative if the RT or template was omitted indicating that DNA was not present and the reagents were not contaminated. A Welch's t-test showed the incubation of culturable, healthy cells in $\mathrm{R}$ broth significantly decreased the transcription of $c d r A(P=0.042)$ (Fig. 2, time zero). Compared to time zero (healthy cells), the oxygen stressed cells showed a decreased expression of $c d r A$ (Fig. 2A). Cells exposed to atmospheric oxygen for $24 \mathrm{~h}$ showed a large increase in $c d r A$ transcription after the addition of regrowth medium at $24 \mathrm{~h}(P=0.001)$. After $72 \mathrm{~h}$ of oxygen exposure and subsequent resuscitation, there was a small increase in $c d r A$ expression $(P=0.226)$ but after $168 \mathrm{~h}$ of oxygen stress and resuscitation, transcription was not significantly different $(P=0.211)$ (Fig. 2A). Transcription of the $c d r A$ gene during nutrient deprivation differed from the levels seen during oxygen stress (Fig. 2B). Compared to the healthy cells, the nutrient deprived cells had less expression of $c d r A$ but the levels decreased less drastically than oxygen stressed cells over time. Expression of $c d r A$ in nutrient deprived cells was decreased after treatment with the $\mathrm{R}$ broth at each time point examined $(P=0.078, P<0.000$, and $P=0.089$, corresponding to differences in mean $c d r A$ transcription before and after resuscitation at 24,72 , and $168 \mathrm{~h}$ ) (Fig. 2B). 

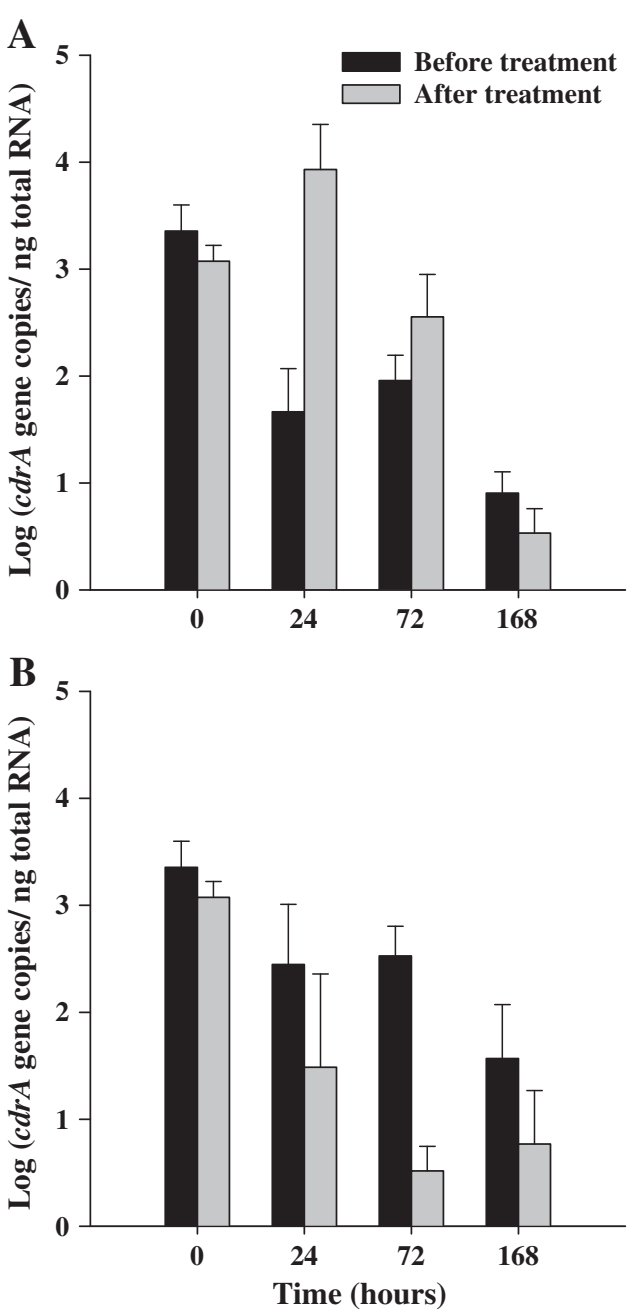

Fig. 2. Transcription of the gene $c d r A$ in A) oxygen stressed and B) nutrient deprived H. pylori before and after treatment with $\mathrm{R}$ broth. The X-axis indicates the hours of stress exposure. Graphs represent mean measurements of three biological replicates and error bars represent \pm 1 standard deviation.

\subsection{Selective and differential growth medium}

To assess whether the previously described resuscitation method could potentially be used to grow and presumptively indicate stressed H. pylori, the $\mathrm{R}$ broth was modified into a selective and differential $\mathrm{R}$ slant (Table 2). Oxygen stressed and nutrient deprived $H$. pylori were heat shocked as previously described, added to the $\mathrm{R}$ slant, and

Table 2

Ingredient list of R slant and broth.

\begin{tabular}{|c|c|c|c|}
\hline Slant ingredient & Quantity & Broth ingredient & Quantity \\
\hline \multicolumn{4}{|c|}{ Before autoclaving $p H 6.7$} \\
\hline Brucella broth & $28 \mathrm{~g} / \mathrm{L}$ & Brucella broth & $28 \mathrm{~g} / \mathrm{L}$ \\
\hline Agar & $7 \mathrm{~g} / \mathrm{L}$ & HEPES & $10 \mathrm{mM}$ \\
\hline HEPES & $10 \mathrm{mM}$ & $\mathrm{CuSO}_{4}$ & $0.2 \mu \mathrm{M}$ \\
\hline $\mathrm{CuSO}_{4}$ & $0.2 \mu \mathrm{M}$ & $\mathrm{MnSO}_{4}$ & $0.2 \mu \mathrm{M}$ \\
\hline $\mathrm{MnSO}_{4}$ & $0.2 \mu \mathrm{M}$ & $\mathrm{ZnSO}_{4}$ & $3 \mu \mathrm{M}$ \\
\hline $\mathrm{ZnSO}_{4}$ & $3 \mu \mathrm{M}$ & & \\
\hline \multicolumn{4}{|l|}{ After autoclaving } \\
\hline $\mathrm{FeSO}_{4}$ & $50 \mu \mathrm{M}$ & $\mathrm{FeSO}_{4}$ & $50 \mu \mathrm{M}$ \\
\hline $\mathrm{MgCl}_{2}$ & $250 \mu \mathrm{M}$ & $\mathrm{MgCl}_{2}$ & $250 \mu \mathrm{M}$ \\
\hline \multirow[t]{3}{*}{ Sodium pyruvate } & $250 \mathrm{mg} / \mathrm{L}$ & Sodium pyruvate & $250 \mathrm{mg} / \mathrm{L}$ \\
\hline & & Human blood serum & $2 \%$ \\
\hline & & Human blood lysate & $2 \%$ \\
\hline
\end{tabular}

incubated microaerophilically for $48 \mathrm{~h}$. To check for consistency with results obtained from the $\mathrm{R}$ broth, aliquots of the broth from the $\mathrm{R}$ slant were plated onto TSA with sheep blood after the $48 \mathrm{~h}$ incubation period. The addition of antibiotics, urea, phenol red and the slight acidification of the media did not change the overall results seen in the resuscitation with $\mathrm{R}$ broth. Positive control $\mathrm{H}$. pylori in early log phase showed the most robust growth on the slant agar surface and also showed confluent growth after subculturing onto TSA with sheep blood. The R slant color changed from a yellow-orange (phenol red at pH5.7) to a deep red color during incubation with healthy H. pylori indicating an active urease enzyme that hydrolyzed urea into ammonia and bicarbonate, thereby increasing the $\mathrm{pH}$ of the medium and causing the color change (Fig. 3 ).

Consistent with results seen in the R broth, oxygen stressed cells (both 24 and $72 \mathrm{~h}$ stress treatments) showed growth on the surface of the R agar slant. Growth on the R slant inoculated with oxygen stressed cells was less robust than the positive control $\mathrm{R}$ slants. The characteristic color change associated with urease activity was slightly less red than the positive control slants indicating decreased urease activity compared to healthy cells. Nutrient deprived $H$. pylori behaved similarly, with growth on the agar slant occurring only after shorter periods of stress $(24 \mathrm{~h})$. After $72 \mathrm{~h}$ of nutrient deprivation, no visible growth was observed on the slant or after subculturing and there was only a slight change in color of the slant compared to the negative control, indicating lower levels of urease activity. The low level of urease activity is likely attributed to the dormant and nonculturable cells that were not able to be resuscitated using this method.

\section{Discussion}

Because reliable growth of stressed H. pylori is essential to proving the viability of the organism, considerable time and effort have been

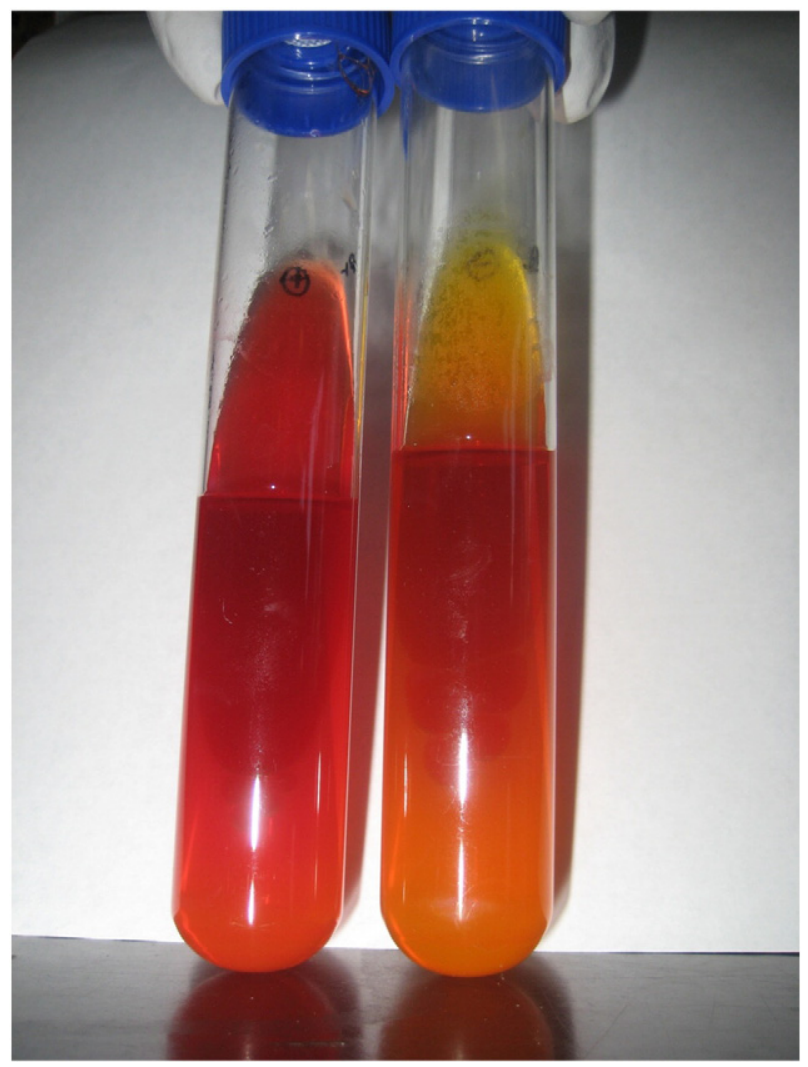

Fig. 3. Depicts the selective and differential R slant. Slant on left is inoculated with early $\log$ phase H. pylori cells. The slant on the right is the negative control inoculated with sterile PBS. 
expended to characterize and improve recovery of these cells. This has led to many formulations of nutrient rich media that are optimized to produce robust growth of $H$. pylori (Coudron and Stratton, 1995; Degnan et al., 2003; Testerman et al., 2001). Since the bacterium is sensitive to oxygen (Donelli et al., 1998) it must be grown in a microaerophilic environment with limited exposure to atmospheric conditions. It is well known that exposure to oxygen and starvation conditions lead to a nonculturable state in vitro (Kusters et al., 1997) and that varying temperatures affect the time it take to lose culturability (Adams et al., 2003). This study has attempted to describe two conditions under which nonculturable $H$. pylori may be recovered. The stress conditions were carefully chosen; it was important to make stepwise changes to the stress treatments so that differences in results could be attributed to specific changes. Accordingly, the temperature was not changed for either stress condition examined in this study. The main criteria for viability in this study was the ability to form a colony on a solid agar, however the ability to produce mRNA transcripts was used as an indication of viability as well.

The incubation of early $\log$ phase $H$. pylori (initially grown microaerophilically, in a TSA/TSB biphasic slant) in R broth did not increase the total number of cells but did increase the number of culturable cells ( $\mathrm{CFU} / \mathrm{ml})$. This showed that even in a growing in vitro culture, a portion of the cells can be nonculturable. Because the total number of cells did not significantly change and the colony forming units nearly account for every cell enumerated microscopically, it was concluded that the nonculturable cells were resuscitated rather than stimulated to divide and regrow. This is consistent with the findings by Andersen et al. (1997) who saw the morphological conversion of individual cells, from a coccoid back to a rod, when nonculturable H. pylori regained culturability.

Oxygen stressed and nutrient deprived $H$. pylori exhibited differential growth in response to $\mathrm{R}$ broth. H. pylori that had access to ample nutrients but were stressed by atmospheric levels of oxygen had greater recovery of culturable colonies than cells that were suspended in sterile water and subjected to nutrient deprivation (also under atmospheric oxygen conditions). These results generally agree with other reports that found that $H$. pylori could be resuscitated using the proper nutrients and human blood products such as erythrocyte lysate and/or serum (Andersen et al., 1997; Kurokawa et al., 1999). Our study has elaborated on these findings, showing that the recovery of stressed $H$. pylori depends on the type of stress and the length of time the organisms are exposed to that stress. It is important to note that it is not possible to conclude whether true resuscitation has occurred in either of the stress treatments we investigated. Because not every cell was recovered into a colony forming unit and our cultures were relatively dense, it is impossible to discern whether a small subpopulation has retained the ability to divide and regrow or if the cells that formed colonies were actually resuscitated.

RNA levels provide some insight into the overall fitness of the populations under study. RNA levels decreased very quickly under oxygen stress while nutrient deprived cells had a slower decline in the quantity of RNA, eventually declining to levels similar to the oxygen stressed cells. After resuscitation, the oxygen stressed cells maintained RNA levels when recoverable cells were present, while nutrient deprived cells had decreased RNA yields after resuscitation at each time point. This finding is consistent with culture results that showed only a small portion of the cells were stimulated to regrow after treatment with $\mathrm{R}$ broth and subsequent subculture on a solid agar, and supports the idea that a small portion of the total number of cells is responsible for the recoverable cells.

The $c d r A$ gene was chosen for study due to its putative role in cell morphology and repression of growth (Takeuchi et al., 1998). Takeuchi and co workers (1998) found that the $c d r A$ gene had a high sequence similarity with the ftsK/SpoIIIE family of proteins that are important for cell division in E. coli. The experimental conditions used by Takeuchi et al. $(1998,2006)$ caused the formation of non-dividing filamentous cells similar to the dominant forms observed under nutrient deprivation in this study. In those studies, $c d r A$ disrupted mutants had greater culturable colony counts and maintained short rod cell morphologies longer under high salt conditions than cells with an intact $c d r A$ gene, indicating a role in repression of cell division and cell morphology. Interestingly, the two stress treatments had differential expression of $c d r A$ before and after the resuscitation treatment. It was expected that if $c d r A$ played a role in the loss in culturability seen in $H$. pylori, there would be an increase in $c d r A$ transcription when culturability was lost. However, both stress treatments resulted in decreased expression of $c d r A$, at varying levels. Oxygen stressed cells had decreased expression of this gene compared to healthy cells (consistent with nutrient deprived cells) which was then significantly increased by resuscitation. It is possible that the observed increase in transcription after treatment with $\mathrm{R}$ broth, seen only in oxygen stressed cells, could be related to changes in the cell morphology as a result of the resuscitation. Because transcription of this gene was variable depending on the stress treatment, it likely does not represent a key gene involved in the loss in culturability seen in $H$. pylori during stress, but may be important for morphological conversions of oxygen stressed cells during regrowth under more favorable conditions.

It is known that $H$. pylori convert to a coccoid morphology as part of its normal stationary phase of growth and under stress, and this process is likely adaptive (Azevedo et al., 2007). However, there is contradictory evidence regarding the association between the loss in culturablilty and the cell morphology. Adams et al. (2003) studied the loss in culturability using membrane diffusion chambers inoculated with $H$. pylori and suspended in a natural freshwater environment. They observed that membrane integrity and total numbers of cells were maintained for long periods of time while culturability was lost early on and cell morphology was variable. Consistent with that report, total cell numbers did not drastically decline during stress and cell morphology did not dictate whether the cell was nonculturable in vitro. Depending on the length of time $H$. pylori is outside the mammalian host, the age of the individual cell, and the particular stress that is present, it is likely that either spiral or coccoid forms may be present and that resuscitation will vary depending on those factors.

Although it has been well documented, it is unknown why starved cells behave differently than cells subjected to oxygen stress alone (Azevedo et al., 2006; Donelli et al., 1998; Shahamat et al., 1993). Resuscitation of culturable cells occurs under nutritionally specific conditions and has been shown to be enhanced by heat shock in $V$. cholerae and H. pylori (Kurokawa et al., 1999; Wai et al., 1996). Certainly the presence of nutrients is a major difference that dictates specific survival strategies in H. pylori. Bloomfield et al. (1998) have proposed that the rapid change in nutrients utilized in most resuscitation experiments results in nonculturability due to "explosive transport". This is the rapid transport of nutrients into a cell resulting from the cells attempt to utilize the organic nutrients that are present, also known as nutrient shock. This idea is supported by the finding that starved cells had decreased recovery compared to cells under oxygen stress with available nutrients. A decrease in total RNA and $c d r A$ transcription was also observed after nutrient deprived cells were incubated in the nutrient rich medium further suggesting decreased viability as a result of nutrient shock as a factor in the lower efficacy of the resuscitation assay. The cells in the oxygen stress treatment may not have undergone explosive transport because they were never nutrient limited. The idea of explosive transport is supported by the findings of Azevedo et al. (2004) who found that nutrient shock was a major factor in recovery of $H$. pylori from water and by Nilsson et al. (2002) who found that ATP production was increased dramatically with the addition of human erythrocytes. 
Because of our interest in growing stressed $H$. pylori in the presence of antimicrobials and differential compounds, the $\mathrm{R}$ broth was adapted into a selective and differential biphasic slant. This slant utilized antimicrobials known to select against a wide variety normal flora of drinking water (Degnan et al., 2003; Stevenson et al., 2000). The addition of urea and phenol red, combined with slight acidification of the medium ( $\mathrm{pH}$ 5.7) allowed the presumptive indication of $H$. pylori when it was inoculated into the slant. This strategy has been successfully used in research attempting to isolate H. pylori from complex biological samples (Degnan et al., 2003). By adding $\mathrm{R}$ broth to the selective and differential biphasic slant based on the same medium it was possible to recover $H$. pylori. This slant also gave an indication of the urease activity by a qualitative assessment of the color change. Although this method has potential for the regrowth of stressed $H$. pylori, there are limitations to the length of time the organism can be stressed and then recovered with this growth medium.

The length of time H. pylori is exposed to an unfavorable condition has been shown to drastically affect culturability and has been well characterized (Donelli et al., 1998; Kusters et al., 1997; Shahamat et al., 1993). Typically, cells under nutrient deprivation at cold temperatures retain viability longer while starvation at warmer temperatures is known to cause a stringent response (Adams et al., 2003; Shahamat et al., 1993). It has also been observed that changing the oxygen concentration above or below the optimal level required by $H$. pylori results in a concomitant decrease in culturable cells (Donelli et al., 1998). More investigation will be required to completely define the conditions under which $H$. pylori can be recovered from the nonculturable state.

In summary, an optimized resuscitation medium that shows promise for use on nonculturable H. pylori has been developed. The longer term goal for this research is to develop a method that potentially allows growth of stressed $H$. pylori, with the added benefit of selection and presumptive indication. The data suggests that stressed $H$. pylori from pure cultures will regrow using this approach, and brings closer the elusive goal of a monitoring tool for this environmental pathogen. Additionally, not all stress conditions are equal and that the potential for resuscitation and, therefore overall viability, is strongly affected by the type of stress and the length of exposure. These results are pertinent to researchers studying H. pylori physiology as well as individuals concerned with regrowing $H$. pylori from the environment.

\section{Acknowledgements}

The authors would like to thank Erica Spiritos for her cheerful assistance in the laboratory. This work was supported by the National Institute for Health, Center for Native Health Partnerships, (M201-10W2724). Dr. Ford is supported in part by a grant from the U.S. Environmental Protection Agency's Science to Achieve Results (USEPA STAR) program and Crystal Richards is supported by a US-EPA STAR Fellowship. Although the research described in the article has been funded in part by the U.S. Environmental Protection Agency's STAR program through grant numbers RD833706 and FP916936, it has not been subjected to any EPA review and therefore does not necessarily reflect the views of the Agency, and no official endorsement should be inferred.

\section{References}

Adams, B.L., Bates, T.C., Oliver, J.D., 2003. Survival of Helicobacter pylori in a natural freshwater environment. Appl. Environ. Microbiol. 69, 7462-7466.

Andersen, A.P., Elliott, D.A., Lawson, M., Barland, P., Hatcher, V.B., Puszkin, E.G., 1997.

Growth and morphological transformations of Helicobacter pylori in broth media. J. Clin. Microbiol. 35, 2918-2922.

Anonymous, 2005. Product information sheet for ATCC ${ }^{\circledR}$ 700392. American Type Culture Collection, Manassas, VA, pp. 1-2.
Asaka, M., Sepulveda, A.R., Sugiyama, T., Graham, D.Y., 2001. Gastric cancer. In: Mobley, H.L.T., Mendz, G.L., Hazell, S.L. (Eds.), Helicobacter pylori: physiology and genetics. American Society for Microbiology, Washington, D.C., pp. 481-498.

Azevedo, N.F., Pacheco, A.P., Keevil, C.W., Vieira, M.J., 2004. Nutrient shock and incubation atmosphere influence recovery of culturable Helicobacter pylori from water. Appl. Environ. Microbiol. 70, 490-493.

Azevedo, N.F., Pacheco, A.P., Keevil, C.W., Vieira, M.J., 2006. Adhesion of water stressed Helicobacter pylori to abiotic surfaces. J. Appl. Microbiol. 101, 718-724.

Azevedo, N.F., Almeida, C., Cerqueira, L., Dias, S., Keevil, C.W., Vieira, M.J., 2007. Coccoid form of Helicobacter pylori as a morphological manifestation of cell adaptation to the environment. Appl. Environ. Microbiol. 73, 3423-3427.

Bellack, N.R., Koehoorn, M.W., MacNab, Y.C., Morshed, M.G., 2006. A conceptual model of water's role as a reservoir in Helicobacter pylori transmission: a review of the evidence. Epidemiol. Infect. 134, 439-449.

Bloomfield, S.F., Stewart, G.S.A.B., Dodd, C.E.R., Booth, I.R., Power, E.G.M., 1998. The viable but not culturable phenomenon explained? Microbiol. Commun. 144, 1-3.

Bode, G., Mauch, F., Malfertheiner, P., 1993. The coccoid forms of Helicobacter pylori. Criteria for their viability. Epidemiol. Infect. 111, 483-490.

Bunn, J.E.G., MacKay, W.G., Thomas, J.E., Reid, D.C., Weaver, L.T., 2002. Detection of Helicobacter pylori DNA in drinking water biofilms: implications for transmission in early life. Lett. Appl. Microbiol. 34, 450-454.

Byrd, J., 2000. Morphological changes leading to the nonculturable state. In: Colwell, R.R., Grimes, J.D. (Eds.), Nonculturable microorganisms in the environment. American Society for Microbiology, Washhington, D. C., pp. 7-18.

Cellini, L., Robuffo, I., Di Campli, E., Di Bartolomeo, S., Taraborelli, T., Dainelli, B., 1998. Recovery of Helicobacter pylori ATCC 43504 from a viable but not culturable state: regrowth or resuscitation? APMIS 106, 571-579.

Conway, T., Schoolnik, G.K., 2003. Microarray expression profiling: capturing a genomewide portrait of the transcriptome. Mol. Microbiol. 47, 879-889.

Coudron, P.E., Stratton, C.W., 1995. Factors affecting growth and susceptibility testing of Helicobacter pylori in liquid media. J. Clin. Microbiol. 33, 1028-1030.

Degnan, A.J., Sonzogni, W.C., Standridge, J.H., 2003. Development of a plating medium for selection of Helicobacter pylori from water samples. Appl. Environ. Microbiol. 69, 2914-2918.

Donelli, G., Matarrese, P., Fiorentini, C., Dainelli, B., Taraborelli, T., Di Campli, E., Di Bartolomeo, S., Cellini, L., 1998. The effect of oxygen on the growth and cell morphology of Helicobacter pylori. FEMS Microbiol. Lett. 168, 9-15.

Enroth, H., Wreiber, K., Rigo, R., Risberg, D., Uribe, A., Engstrand, L., 1999. In vitro aging of Helicobacter pylori: changes in morphology, intracellular composition and surface properties. Helicobacter 4, 7-16.

Gribbon, L. T., Barer, M. R. 1995. Oxidative metabolism in nonculturable Helicobacter pylori and Vibrio vulnificus cells studied by substrate enhanced tetrazolium reduction and digital imaging processing. Appl. Environ. Microbiol. 61, 3379-3384.

Janzon, A., Sjoling, A., Lothigius, A., Ahmed, D., Qadri, F., Svennerholm, A.M., 2009. Failure to detect Helicobacter pylori DNA in drinking and environmental water in Dhaka, Bangladesh, using highly sensitive real-time PCR assays. Appl. Environ. Microbiol. 75, 3039-3044.

Kivi, M., Tindberg, Y., 2006. Helicobacter pylori occurrence and transmission: a family affair? Scand. J. Infect Dis. 38, 407-417.

Knight, I.T., 2000. Molecular genetic methods for detection and identification of viable but nonculturable microorganisms. In: Colwell, R.R., Grimes, D.J. (Eds.), Nonculturable microorganisms in the environment. Washington D. C., American Society for Microbiology, pp. 77-85.

Kurokawa, M., Nukina, M., Nakanishi, H., 1999. Resuscitation from the viable but non culturable state of Helicobacter pylori. Kansenshogaku Zasshi 73, 15-19.

Kusters, J.G., Gerrits, M.M., VanStrijp, J.A.G., VandenbrouckeGrauls, C., 1997. Coccoid forms of Helicobacter pylori are the morphologic manifestation of cell death. Infect. Immun. 65, 3672-3679.

Kutner, M., Nachtsheim, C., Neter, J., Li, W., 2004. Applied Linear Statistical Models, Fifth ed. McGraw-Hill/Irwin, New York.

Marshall, B.J., 1995. Helicobacter pylori-the etiologic agent for peptic ulcer. J. Amer. Med. Assoc. 274, 1064-1066.

Moss, S.F., Malfertheiner, P., 2007. Helicobacter and gastric malignancies. Helicobacter $12,23-30$.

Narikawa, S., Kawai, S., Aoshima, H., Kawamata, O., Kawaguchi, R., Hikiji, K., Kato, M., Iino, S., Mizushima, Y., 1997. Comparison of the nucleic acids of helical and coccoid forms of Helicobacter pylori. Clin. Diag. Lab. Immunol. 4, 285-290.

Nilsson, H.O., Blom, J., Abu Al-Soud, W., Ljungh, A., Andersen, L.P., Wadstrom, T., 2002. Effect of cold starvation, acid stress, and nutrients on metabolic activity of Helicobacter pylori. Appl. Environ. Microbiol. 68, 11-19.

Oliver, J.D., 2000. The public health significance of viable but not culturable bacteria. In: Colwell, R.R., Grimes, D.J. (Eds.), Nonculturable Microorganisms in the Environment. American Society for Microbiology, Washington, D. C., pp. 277-300.

Oliver, J.D., 2010. Recent findings on the viable but nonculturable state in pathogenic bacteria. FEMS Microbiol. Rev. 34, 415-425.

Saito, N., Konishi, K., Sato, F., Kato, M., Takeda, H., Sugiyama, T., Asaka, M., 2003. Plural transformation-processes from spiral to coccoid Helicobacter pylori and its viability. J. Infect. 46, 49-55.

Sasaki, K., Tajiri, Y., Sata, M., Fujii, Y., Matsubara, F., Zhao, M.G., Shimizu, S., Toyonaga, A., Tanikawa, K., 1999. Helicobacter pylori in the natural environment. Scand. J. Infect Dis. 31, 275-280.

Shahamat, M., Mai, U., Paszkokolva, C., Kessel, M., Colwell, R.R., 1993. Use of autoradiography to assess viability of Helicobacter pylori in water. Appl. Environ. Microbiol. 59, 1231-1235. Sheridan, G.E.C., Masters, C.I., Shallcross, J.A., Mackey, B.M., 1998. Detection of mRNA by reverse transcription-PCR as an indicator of viability in Escherichia coli cells. Appl. Environ. Microbiol. 64, 1313-1318. 
Stevenson, T.H., Lucia, L.M., Acuff, G.R., 2000. Development of a selective medium for isolation of Helicobacter pylori from cattle and beef samples. Appl. Environ. Microbiol. 66, 723-727. Takeuchi, H., Shirai, M., Akada, J.K., Tsuda, M., Nakazawa, T., 1998. Nucleotide sequence and characterization of cdrA, a cell division-related gene of Helicobacter pylori. J. Bacteriol. 180, 5263-5268.

Takeuchi, H., Nakazawa, T., Okamoto, T., Shirai, M., Kimoto, M., Nishioka, M., Con, S.A Morimoto, N., Sugiura, T., 2006. Cell elongation and cell death of Helicobacter pylor is modulated by the disruption of cdrA (cell division-related gene A). Microbiol. Immunol. 50, 487-497.

Testerman, T.L., McGee, D... Mobley, H.L.T., 2001. Helicobacter pylori growth and urease detection in the chemically defined medium Ham's F-12 nutrient mixture. J. Clin. Microbiol. 39, 3842-3850.
Testerman, T.L., Conn, P.B., Mobley, H.L.T., McGee, D.J., 2006. Nutritional requirements and antibiotic resistance patterns of Helicobacter species in chemically defined media. J. Clin. Microbiol. 44, 1650-1658.

United States Environmental Protection Agency, 1998. Guidance for Data Quality Assessment-Practical Methods for Data Analysis. Office of Research and Development, Washington, D. C.

Veldhuyzen van Zanten, S.J., Sherman, P.M., 1994. Helicobacter pylori infection as a cause of gastritis, duodenal ulcer, gastric cancer, and nonulcer dyspepsia-a systematic overview. Can. Med. Assoc. J. 150, 177-185.

Wai, S.N. Moriya, T, Kondo, K., Misumi, H., Amako, K, 1996. Resuscitation of Vibrio cholerae 01 strain TSI-4 from a viable but nonculturable state by heat shock. FEMS Microbiol. Lett. 136, 187-191. 